\title{
STRATEGI PENGEMBANGAN USAHA MIKRO KECIL DAN MENENGAH DI PROVINSI DAERAH ISTIMEWA YOGYAKARTA*
}

\author{
Edy Suandi Hamid ${ }^{1}$ dan Y. Sri Susilo ${ }^{2}$ \\ ${ }^{1}$ Fakultas Ekonomi Universitas Islam Indonesia \\ Condong catur, Depok, Sleman, Yogyakarta 55283, Indonesia Telepon : +62 274881546 \\ 2 Fakultas Ekonomi Universitas Atmajaya Yogyakarta \\ Kampus II Gedung Bonaventura Jalan Babarsari 43, Yogyakarta 55281, Telepon : +62 274487711
}

Diterima 23 Nopember 2010/Disetujui 7 Maret 2011

\begin{abstract}
This research aims to arrange the correct and operational strategies for developing small and medium enterprises (SMEs) in Daerah Istimewa Yogyakarta Province. It also needs to be known and analyzed the SMEs profile. Data used is primary and secondary data. Primary data obtained through field surveys, while secondary data obtained from various publication sources. Method of analysis used is descriptive approach. Associated with the various problems faced by SMEs, there are some strategies needed to overcome them. To develop the SMEs is not only charged to the SMEs themselves but also supported by all stakeholders. The support expected to come from business associations, colleges, related agencies in the area of regency/city governments in DIY. Moreover, government policy is needed to encourage SMEs development. The SMEs development in DIY basically is the acceleration of the SMEs transformation from formation phase to stabilization phase.
\end{abstract}

Keywords: development strategy, SMEs, stakeholder, small industry

Abstrak: Penelitian ini bertujuan menyusun strategi yang operasional dan tepat untuk mengembangkan Usaha Mikro Kecil dan Menengah (UMKM) di Provinsi Daerah Istimewa Yogyakarta (DIY). Profil UMKM juga perlu dikenali dan dianalisis. Penelitian ini menggunakan data primer dan sekunder. Data primer diperoleh dari survei lapangan, sedangkan data sekunder diperoleh dari berbagai sumber publikasi. Metode analisis yang digunakan adalah pendekatan deskriptif. Berkaitan dengan berbagai masalah yang dihadapi oleh UMKM, ada beberapa strategi untuk mengatasinya. Pengembangan UMKM tidak hanya oleh UMKM saja, tetapi juga harus didukung semua stakeholder. Dukungan diharapkan datang dari asosiasi bisnis, perguruan tinggi, dan instansi terkait di kabupaten/kota di DIY. Kebijakan pemerintah juga diperlukan untuk mendorong pengembangan UMKM. Pengembangan UMKM di DIY merupakan percepatan transformasi UMKM dari fase formasi menuju fase stabilisasi.

Kata kunci: strategi pengembangan, UMKM, stakeholder, industri kecil

\section{PENDAHULUAN}

Pada tahun 2008, kontribusi Usaha Mikro Kecil dan Menengah (UMKM) terhadap pendapatan devisa nasional melalui ekspor nonmigas me-

\footnotetext{
* Diringkas dari hasil riset dengan judul "Studi Pengembangan Model UMKM di Provinsi DIY" yang dilakukan oleh Tim Peneliti ISEI Cabang Yogyakarta. Riset ini dibiayai dari Pengurus Pusat ISEI Jakarta.
}

ngalami peningkatan sebesar Rp40,75 triliun atau 28,49 persen yaitu dengan tercapainya angka sebesar Rp183,76 triliun atau 20,17 persen dari total nilai ekspor nonmigas nasional (www.bps.go.id). Selanjutnya pada tahun 2008, produk domestik bruto (PDB) nasional atas harga konstan tahun 2000 sebesar Rp1.997,73 triliun, kontribusi UMKM sebesar Rp1.165,26 triliun atau 58,33 persen dari total PDB. Harga 
konstan tahun 2000 nasional mengalami perkembangan sebesar Rp115,41 triliun atau 6,13 persen dari tahun 2007. Kemudian pada tahun 2008, UMKM mampu menyerap tenaga kerja sebesar 90.896.270 orang atau 97,04 persen dari total penyerapan tenaga kerja yang ada. Jumlah ini meningkat sebesar 2,43 persen atau 2.156.526 orang dibandingkan tahun 2007 (www.depkop. go.id).

Berdasarkan data tahun 2005, jumlah UMKM di Provinsi Daerah Istimewa Yogyakarta (DIY) sebanyak 93.854 unit atau sebesar 99,98 persen dari total unit usaha yang ada di wilayah tersebut (Astungkoro, 2010). Jumlah tenaga kerja yang diserap oleh UMKM sebanyak 37.260 orang atau sebesar 95,39 persen dari total tenaga kerja yang diserap oleh unit usaha di Provinsi DIY. Selanjutnya pada tahun 2007, jumlah UMKM di Provinsi DIY menurun menjadi 88.862 unit usaha, namun persentasenya tetap sebesar 99,98 persen. Jumlah tenaga kerja yang terserap oleh UMKM pada tahun 2007 sebanyak 36.426 orang atau sebesar 96,04 persen dari total tenaga kerja. Penurunan jumlah unit usaha dan tenaga kerja secara absolut tersebut terkait dengan terjadinya gempa bumi yang terjadi pada tahun 2006. Berdasarkan data jumlah unit usaha dan tenaga kerja tersebut, maka UMKM di Provinsi DIY mempunyai kontribusi yang penting dan strategis dalam perekonomian daerah.

Sehubungan dengan kontribusi UMKM tersebut, maka pemberdayaan dan pengembangan UMKM menjadi hal yang perlu dilakukan secara berkesinambungan. Bagaimanakah strategi pengembangan UMKM di Provinsi DIY yang seharusnya dilakukan? Jawaban dari pertanyaan tersebut menjadi fokus penelitian ini. Untuk menjawab, perlu ditelusuri terlebih dahulu berbagai masalah yang dihadapi oleh UMKM di Provinsi DIY. Demikian pula perlu dilihat strategi survival yang telah dilakukan oleh UMKM agar tetap mampu bertahan menjalankan usahanya.

Masalah dan Kinerja UMKM di Provinsi DIY. Sri Susilo dan Sutarta (2004) melakukan kajian masalah dan dinamika industri kecil pascakrisis ekonomi pada tahun 1998 di Provinsi DIY. Besar sampel mencakup 200 unit usaha yang mencakup industri pengolahan makanan, industri kerajinan kulit, industri gerabah, dan industri kerajinan lainnya. Metode pengumpulan data dilakukan dengan survei lapangan, wawancara mendalam, dan focus group discussion (FGD). Permasalahan yang dihadapi industri kecil antarkelompok industri mempunyai persamaan dan perbedaan. Persamaan yang menonjol adalah kenaikan harga faktor produksi yang memaksa mereka menaikkan harga jual produk. Masalah yang lain adalah menurunnya tingkat produksi dan employment.

Dalam hal perbedaan masalah yang dihadapi tergantung dari jenis dan karaketristik industri kecil. Ada yang menyatakan masalah pokok yang dihadapi adalah kemampuan bersaing di pasar, pemasaran produk, dan ketersediaan tenaga kerja terampil. Dalam hal dinamika usaha, persamaan di antara mereka terutama dalam diversifikasi produk. Pengusaha industri kecil melakukan diversifikasi dari sisi bahan baku dan hasil produksi. Perbedaan dinamika usaha terjadi dalam hal diversifikasi usaha. Pengusaha industri kecil melakukan diversifikasi usaha yang berbeda sama sekali dengan usaha sebelumnya, namun juga ada yang melakukan diversifikasi usaha yang terkait dengan usaha sebelumnya.

Selanjutnya Sri Susilo (2007) melakukan studi mengenai masalah dan dinamika usaha kecil dengan fokus pedagang klithikan di alunalun selatan Kota Yogyakarta. Survei dilakukan terhadap 40 pedagang klithikan. Pengumpulan data dilakukan dengan kuesioner dan wawancara mendalam. Analisis dilakukan dengan pendekatan deskriptif. Masalah yang dihadapi oleh pedagang klithikan terutama dalam hal: (1) Lokasi usaha; (2) Perijinan; (3) Modal usaha; (4) Kondisi cuaca; dan (5) Pasokan barang dagangan. Dinamika usaha yang dialami oleh pedagang klithikan relatif statis atau sulit untuk berkembang. Hal ini terjadi karena keterbatasan yang ada pada pedagang terutama dalam hal modal dan lokasi usaha.

Kemudian Sri Susilo et al., (2008) melakukan kajian masalah dan kinerja industri kecil pasca gempa di Kabupaten Bantul Provinsi DIY. Survei dilakukan terhadap 100 pengusaha yang tergolong industri skala kecil dan menengah (IKM). Periode survei dilakukan 6-7 
bulan setelah terjadinya gempa 17 Mei 2006. Jenis IKM mencakup industri gerabah dan keramik, industri kerupuk kulit, industri makanan tahu, industri genteng, dan industri kerajinan kulit. Pengumpulan data dilakukan dengan survei lapangan, wawancara mendalam, dan focus group discussion (FGD). Analisis data dilakukan secara deskriptif. Masalah utama yang dihadapi oleh pengusaha pasca gempa adalah ketidakmampuan memenuhi kewajiban finansial terhadap pihak lain dan keterbatasan untuk menambah modal. Masalah lain yang dihadapi adalah menurunnya hasil produksi dan pemasaran hasil produksi. Bagaimana dengan kinerja usahanya? Dengan indikator kinerja tingkat produksi maka sebagian besar unit usaha (65 persen) mengalami penurunan, sedangkan 23 persen produksinya tetap, dan sebanyak 12 persen mengalami penurunan.

Tarigan dan Sri Susilo (2008) melakukan kajian masalah dan kinerja industri kecil pasca gempa untuk kasus industri kerajinan perak di Kota Yogyakarta. Survei dilakukan terhadap 50 pengrajin perak dan pengumpulan data dilakukan dengan kuesioner dan wawancara mendalam. Kegiatan survei lapangan dilakukan pada bulan Desember tahun 2006 atau 7 bulan setelah gempa 27 Mei 2006. Kesimpulan dari riset sebagai berikut: (1) Pengusaha/pengrajin perak menghadapi permasalahan yang terkait dengan terganggunya kegiatan produksi karena adanya kerusakan bangunan serta prasarana produksi; (2) Terganggunya proses produksi menyebabkan berkurangnya jumlah produksi yang berimplikasi pada kemampuan melayani permintaan; (3) Penurunan permintaan pada gilirannya akan mengurangi pendapatan dan berimplikasi pada kemampuan memenuhi kewajiban finansial. Dari aspek kinerja, gempa bumi menyebabkan: (1) Terjadinya rata-rata penurunan jumlah produksi sebesar 43,46 persen; (2) Rata-rata penurunan nilai penjualan sebesar 26 persen.

Strategi Survival UMKM di Provinsi DIY. Berikut kajian yang terkait dengan strategi survival atau bertahan UMKM di Provinsi DIY dalam menghadapi kondisi lingkungan usaha yang berubah. Sri Susilo (2005) melakukan kajian strategi usaha mikro-kecil dengan kasus pedagang warung angkringan di Kota Yogya- karta. Survei dilakukan pada bulan MaretApril 2005 terhadap 50 pedagang warung angkringan. Pengumpulan data dilakukan dengan survei dan wawancara mendalam. Analisis dilakukan dengan pendekatan deskriptif. Strategi atau tindakan yang dilakukan oleh pedagang warung angkringan agar tetap mampu bertahan dalam menajalan usahanya adalah: (1) Melakukan diversifikasi barang dagangan dan diversifikasi usaha. (2) Mentaati peraturan atau imbauan yang diberikan pihak kecamatan/ kelurahan dan menjaga hubungan baik dengan pihak lain (masyarakat sekitar dan pemasok/ juragan) agar tetap dapat berjualan di lokasi usaha saat ini, serta ikut menjaga ketertiban dan kebersihan di sekitar lokasi usaha. (3) Mencoba untuk adaptif terhadap perubahan lingkungan, misalnya perubahan harga, yang mempengaruhi usahanya. (4) Melayani pembeli atau pelanggan dengan baik, termasuk memberikan kesempatan menunda pembayaran.

Selanjutnya Sri Susilo dan Krisnadewara (2007) melakukan riset strategi bertahan industri pascagempa di Yogyakarta. Sampel merupakan pengusaha atau pengrajin skala kecil. Survei mencakup industri gerabah dan keramik, industri makanan tahu, industri genteng, industri kulit, industri kerajinan perak, industri kerupuk kulit, dan industri kerajinan patung/ sovenir. Pengumpulan data dilakukan dengan penyebaran kuesioner dan wawancara mendalam. Strategi yang diterapkan adalah: (1) Berproduksi dengan fasilitas/peralatan terbatas. (2) Berproduksi dengan jumlah bahan baku terbatas. (3) Berproduksi dengan jumlah tenaga kerja terbatas. (4) Berproduksi dengan modal finansial terbatas. (5) Membuka shoow-room/ outlet. (6) Melakukan usaha sampingan. Dalam kasus pengusaha/pengrajin dalam riset ini masalah yang terjadi lebih dari sisi penawaran dari pada sisi permintaan. Oleh karena itu yang lebih penting adalah upaya percepatan pemulihan kembali (recovery) dari usaha, dan hal tersebut diawali dengan melakukan kegiatan produksi. Bagi pengusaha/pengrajin korban gempa, suntikan berupa bantuan modal menjadi sangat berarti. Dengan tambahan modal maka berbagai keterbatasan dalam kegiatan produksi dapat dikurangi/ditekan, sehingga aktivitas produksi akan lebih lancar, dan pada 
gilirannya pasar dapat dilayani dengan baik.

\section{METODE PENELITIAN}

Studi ini merupakan penelitian kebijakan (policy research) yang bertujuan untuk menggali berbagai informasi berkaitan dengan UMKM dalam rangka memberikan rekomendasi pengambilan kebijakan pengembangannya. Berbagai hal berkaitan lokasi, metode sampling, tahapan kerja, dan metode analisis dijelaskan sebagai berikut.

\section{Lokasi Penelitian}

Riset mencakup wilayah 4 kabupaten (Bantul, Sleman, Kulonprogo, Gunungkidul) dan kota Yogyakarta, Provinsi DIY, khususnya pada daerah-daerah sentra industri. Survei lapangan dilakukan pada bulan Januari sampai dengan Februari 2010.

\section{Jenis dan Sumber Data}

Jenis data yang dibutuhkan dalam studi ini berdasarkan sumbernya adalah data: (1) primer; dan (2) sekunder. Data primer biasanya dipersoleh dengan survei lapangan yang menggunakan semua metode pengumpulan data orisinal (Hanke dan Reitsch, 1998). Selanjutnya data primer dapat didefinisikan sebagai data yang dikumpulkan dari sumber-sumber asli (Kuncoro, 2009). Dalam riset ini data primer dikum- pulkan hasil wawancara dengan pengusaha/ pengrajin industri kecil dan berbagai pihak yang telah dipilih menjadi sampel atau responden. Pengertian data sekunder adalah data yang telah dikumpulkan oleh lembaga pengumpul data dan dipublikasikan kepada masyarakat pengguna (Hanke dan Reitsch, 1998). Secara singkat dapat dikatakan bahwa data sekunder adalah data yang telah dikumpulkan oleh pihak lain (Kuncoro, 2009). Dalam riset ini data sekunder diperoleh dari instansi atau dinas terkait di lingkungan Pemerintah Provinsi DIY.

\section{Langkah/Tahapan Kerja}

Studi ini dilakukan secara cross sectional melalui analisis data sekunder dan survei kepada para pelaku UMKM yang berlokasi di Provinsi DIY, yang meliputi empat kabupaten dan kota Yogyakarta. Studi ini dilakukan dalam beberapa langkah kerja sebagaimana terlihat dalam Gambar 1.

Responden dalam studi adalah para pelaku dari berbagai jenis UMKM unggulan produktif yang muncul dari tahap analisis data sekunder. Dalam survei ini jumlah responden yang dijadikan responden adalah 220 UMKM di Provinsi DIY yang terdiri atas 4 kabupaten, yaitu Kabupaten Sleman, Kabupaten Bantul, Kabupaten Kulonprogo, dan Kabupaten Gunungkidul, serta Kota Yogyakarta. Sampel diambil secara purposive sampling (Sekaran and Bougie, 2010).

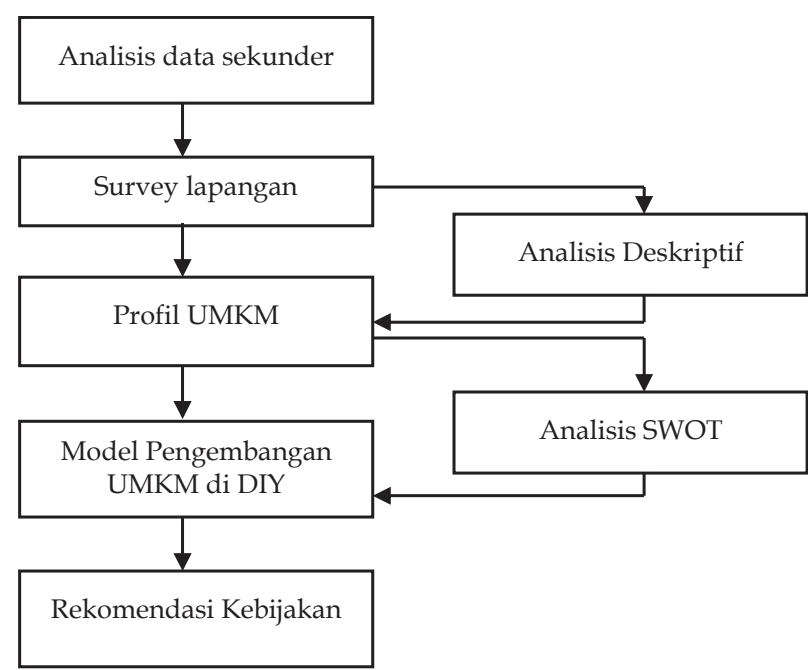

Gambar 1. Langkah Kerja 


\section{Metode Analisis}

Analisis dalam penelitian ini dilakukan dengan pendekatan deskriptif. Analisis deskriptif memberikan gambaran pola-pola yang konsisten dalam data, sehingga hasilnya dapat dipelajari dan ditafsirkan secara singkat dan penuh makna (Kuncoro, 2009). Dalam analisis deskriptif, dilakukan interprestasi atas data dan hubungan yang ada dalam penelitian tersebut. Di samping itu juga dilakukan komparasi antara hasil penelitian dengan hasil-hasil penelitian terkait dan dilakukan korelasi antara hasil-hasil penelitian tersebut dengan teori atau konsep yang relevan (Singarimbun dan Effendi, 1989). Selanjutnya analisis secara deskriptif dapat juga dilakukan dengan teknik statistik yang relatif sederhana, seperti misalnya menggunakan tabel, grafik, dan ukuran tendensi sentral yaitu nilai rata-rata, nilai tengah, dan modus (Kountur, 2003). Dengan mengacu pada pengertian analisis deskriptif tersebut maka sekalipun metode analisis yang digunakan dalam riset ini relatif sederhana, namun dapat memberikan informasi yang memadai sesuai dengan tujuan penelitian.

\section{HASIL DAN PEMBAHASAN}

\section{Profil Responden}

Besar Sampel/Jumlah Responden. Berbagai informasi tentang UMKM di Provinsi D.I. Yogyakarta ditampilkan pada berbagai grafik berikut ini. Pada Tabel 1 dipaparkan komposisi sebanyak 220 unit usaha.

Tabel 1. Besar Sampel

\begin{tabular}{clc}
\hline No & \multicolumn{1}{c}{ Wilayah } & Frekuensi UMKM \\
\hline $\mathbf{1}$ & Kota Yogyakarta & 34 \\
$\mathbf{2}$ & Kabupaten Kulonprogo & 30 \\
$\mathbf{3}$ & Kabupaten Sleman & 31 \\
$\mathbf{4}$ & Kabupaten Bantul & 70 \\
$\mathbf{5}$ & Kabupaten Gunungkidul & 55 \\
& Total & 220 \\
\hline
\end{tabular}

Sumber: Data primer (diolah)

Besar sampel dari Kabupaten Bantul merupakan jumlah terbesar (70 unit usaha), diikuti Kabupaten Gunungkidul (55 unit usaha), Kota
Yogyakarta (34 unit usaha), Kabupaten Sleman (31 unit usaha) dan Kabupaten Kulonprogo (30 unit usaha). Distribusi ini sesuai dengan jumlah UMKM yang menjadi responden di masingmasing daerah tersebut.

Tahun Berdiri UMKM. Berdasarkan hasil survei mayoritas UMKM di Provinsi DIY berdiri sebelum tahun 1990 yaitu sebanyak 36 persen, sedangkan UMKM yang berdiri sejak tahun 2001 sampai dengan tahun 2000 sebanyak 33 persen sedangkan sisanya berdiri tahun 2001-2010 sebanyak 31 persen. Melihat kondisi objektif tersebut maka UMKM di Provinsi DIY berkembang sejak sebelum tahun 1990 (Gambar 2). Pada periode satu dasawarsa terakhir, perkembangan UMKM juga menggembirakan. Hal ini terbukti pada periode tersebut cukup banyak UMKM yang memulai usahanya.

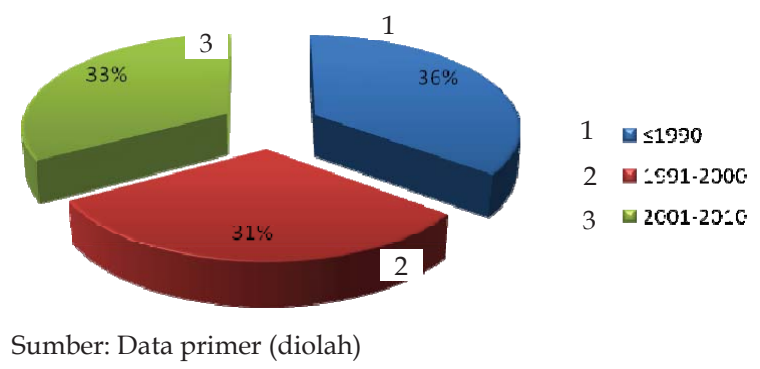

\section{Gambar 2. Tahun Berdiri UMKM di Provinsi DIY}

\section{Bidang Usaha Utama Perusahaan}

Deksripsi UMKM menurut lapangan usahanya, sesuai dengan klasifikasi yang dikeluarkan oleh Disperindagkop dan UKM Provinsi Daerah Istimewa Yogyakarta pada tahun 2009 dapat dibagi dalam kelompok industri pertanian, industri nonpertanian, kerajinan, dan aneka usaha (Gambar 3).

Dari berbagai kelompok tersebut, maka UMKM di Yogyakarta terbanyak beroperasi pada bidang usaha industri pada komoditas yang berkaitan dengan produk pertanian. Hal ini tentu sangat dipengaruhi oleh berbagai hal, yaitu ketersediaan bahan baku, ketersediaan SDM yang sesuai serta skala usaha yang cocok bagi pasar lokal dan regional. Predikat Yog- 
yakarta sebagai kota pendidikan dan tujuan pariwisata memiliki peran besar bagi berkembangnya UMKM yang bergerak pada bidang kerajinan.

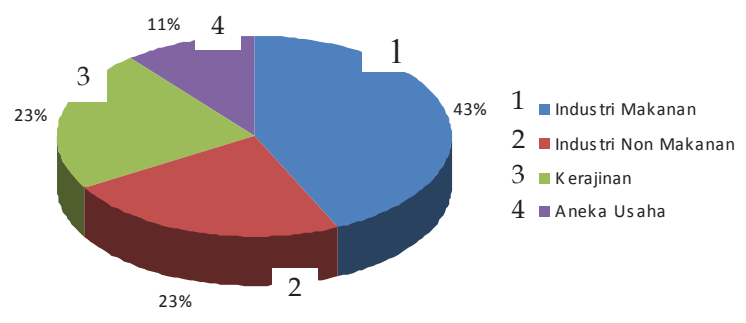

Sumber: Data primer (diolah)

\section{Gambar 3. Komposisi Kelompok Usaha UMKM Menurut Bidang Usaha}

Pada tahun 2006 nilai penjualan sebesar Rp172,6 milyar dan meningkat menjadi Rp173,1 milyar pada tahun 2008. Selanjutnya pada tahun 2009, nilai penjualan produk UMKM yang menjadi responden mencapai Rp174,6 milyar (Gambar 4).

Penghasilan Lain di Luar Usaha. Sebagian pelaku UMKM di Provinsi DIY juga mempunyai penghasilan di luar usaha yang utama. Sebanyak 30 persen responden mengaku mempunyai penghasilan di luar dari usahanya yang pokok. Sisanya sebanyak 70 persen responden tidak mempunyai penghasilan selain dari usahanya yang pokok. Dengan demikian sebagian besar pelaku UMKM mengandalkan penghasilan atau pendapatan dari usahanya yang pokok (Gambar 5).

Adapun UMKM yang menghasilkan peng-

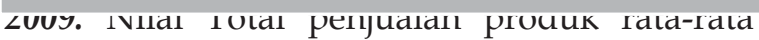
dari tahun ke tahun mengalami kenaikan meskipun relatif kecil.

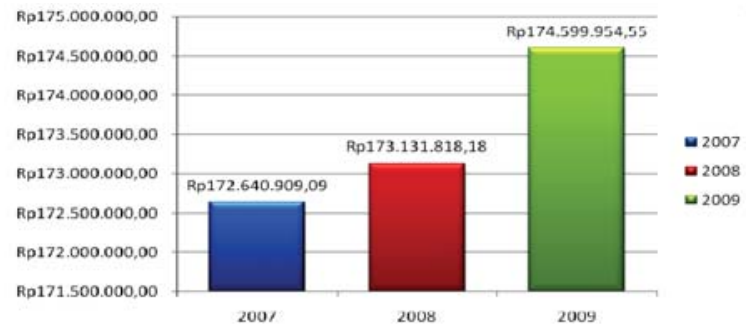

Sumber: Data primer (diolah)

\section{Gambar 4. Rata-rata Nilai Total Penjualan Produk 2007-2009}

\section{Masalah UMKM Provinsi DIY}

Untuk menentukan strategi pengembangan UMKM di Provinsi DI Yogyakarta secara tepat, maka atas dasar hasil survei dapat diketahui berbagai masalah yang dihadapi oleh pelaku UMKM. Berbagai masalah tersebut dapat diklasifikasikan dalam dua aspek, yaitu aspek internal yang dihadapi dalam UMKM, dan aspek eksternal yang berasal dari luar UMKM. Deskripsi ringkas hasil survei tentang kedua aspek tersebut dipaparkan pada Tabel 2. Temuan ini sejalan dengan hasil studi yang dilakukan oleh Sri Susilo dan Sutarta (2004), Sri Susilo (2007), Sri Susilo et al., (2008), dan Tarigan dan Sri Susilo (2008). 
Tabel 2. Berbagai Masalah Internal dan Eksternal UMKM di Provinsi DIY

\begin{tabular}{cll}
\hline No & \multicolumn{1}{c}{ ASPEK INTERNAL } & \multicolumn{1}{c}{ ASPEK EKSTERNAL } \\
\hline 1 & $\begin{array}{l}\text { Kurangnya kemampuan dalam melakukan inovasi } \\
\text { produk }\end{array}$ & $\begin{array}{l}\text { Kesulitan memperluas pangsa pasar baru, } \\
\text { khususnya pasar ekspor }\end{array}$ \\
2 & $\begin{array}{l}\text { Keterbatasan kapasitas produksi untuk memenuhi } \\
\text { permintaan pada waktu yang singkat (kasus-kasus } \\
\text { tertentu) }\end{array}$ & $\begin{array}{l}\text { Ancaman produk-produk sejenis yang berasal } \\
\text { dari impor, khsusunya produk dari China }\end{array}$ \\
3 & $\begin{array}{l}\text { Terbatasnya ketersediaan sumber dana untuk } \\
\text { pengembangan usaha }\end{array}$ & $\begin{array}{l}\text { Kondisi ekonomi yang kurang stabil sehingga } \\
\text { sangat mempengaruhi harga bahan baku dan } \\
\text { harga produk }\end{array}$ \\
4 & $\begin{array}{l}\text { Keterbatasan teknologi proses produksi sehingga } \\
\text { kualitas produk belum mampu memenuhi } \\
\text { permintaan pasar }\end{array}$ & $\begin{array}{l}\text { Kondisi perbankan dengan tingkat bunga tinggi } \\
\text { dan proses kredit yang berbelit }\end{array}$ \\
5 & $\begin{array}{l}\text { Kualitas SDM yang belum memiliki } \\
\text { skill/keterampilan yang diperlukan sehingga } \\
\text { kualitas produk belum optimal }\end{array}$ & $\begin{array}{l}\text { Infrastruktur yang buruk sehingga menambah } \\
\text { biaya distribusi }\end{array}$ \\
6 & $\begin{array}{l}\text { Kelemahan dalam membeli bahan baku, } \\
\text { khususnya untuk memenuhi pembeli skala besar } \\
\text { (big buyer) }\end{array}$ & $\begin{array}{l}\text { Kurangnya kontribusi pihak eksternal, seperti } \\
\text { asosiasi, investor, dan pihak swasta lainnya } \\
\text { dalam mendukung pengembangan UMKM }\end{array}$ \\
7 & $\begin{array}{l}\text { Tingkat harga produk yang relatif tinggi sebagai } \\
\text { akibat biaya produksi yang mahal }\end{array}$ & $\begin{array}{l}\text { Kebijakan pemerintah yang kurang kondusif, } \\
\text { khususnya dalam perpajakan }\end{array}$ \\
\hline
\end{tabular}

Sumber: Data primer (diolah)

\section{Strategi Pengembangan UMKM di Provinsi DIY}

meliputi: (1) Diferensiasi dan pengembangan produk yang beorientasi kualitas; (2) Segmen-

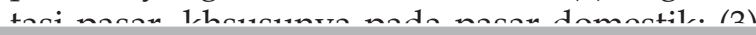

hasil analısis SWUI sepertı dipaparkan pada Tabel 3. Berdasarkan hasil analisis SWOT tersebut, maka strategi pengembangan UMKM

1 Untuk referensi analisis SWOT lihat misalnya Rangkuti (2002) dan Pickton and Wright (1998). pemecahan masalah (problem solving) maupun
yang bersifat pengembangan ke depan (develop-
ment oriented), strategi pengembangan yang di-
tempuh didasarkan kepada pola pendekatan
logis dan komprehensif melalui dua langkah 
Tabel 3. Rumusan Grand Strategy Berdasarkan Analisis SWOT

\begin{tabular}{|c|c|c|}
\hline & Kekuatan (S) & Kelemahan (W) \\
\hline & $\begin{array}{l}\text { - Produk UMKM bersifat khas dan } \\
\text { unik } \\
\text { - Ketersediaan bahan baku lokal } \\
\text { - Ketersediaan tenaga kerja yang } \\
\text { memadai }\end{array}$ & $\begin{array}{l}\text { - Desain produk yang relatif } \\
\text { sederahana } \\
\text { - Mesin dan peralatan produksi } \\
\text { yang relatif tua } \\
\text { - Kurangnya kontribusi pihak } \\
\text { eksternal }\end{array}$ \\
\hline Peluang $(\mathrm{O})$ & Strategi S-O & Strategi W-O \\
\hline $\begin{array}{l}\text { - Terbukanya peluang pasar } \\
\text { ekspor dan domestik } \\
\text { - Peningkatan permintaan } \\
\text { produk yang variatif dan } \\
\text { berorientasi kualitas }\end{array}$ & $\begin{array}{l}\text { - Diferensiasi dan pengembangan } \\
\text { produk yang beorientasi kualitas } \\
\text { - Segmentasi pasar, khsusunya } \\
\text { pada pasar domestik } \\
\text { - Pengembangan produksi } \\
\text { herhasis sımmer dava lnkal }\end{array}$ & $\begin{array}{l}\text { Pengembangan desain produk } \\
\text { yang lebih variatif } \\
\text { - Pengembangan proses produksi } \\
\text { dengan revitalisasi mesin dan } \\
\text { peralatan yang lebih modern }\end{array}$ \\
\hline
\end{tabular}

sěktor/kelompok industri, ditempuh langkahlangkah yang dituangkan dalam program pengembangan UMKM. Meskipun pendekatan pengembangan seperti di atas dapat diterapkan di semua skala satuan obyek pembinaan dari level sektor ataupun kelompok/cabang industri di tingkat nasional/daerah secara makro, sampai tingkat sentra industri dan unit usaha secara mikro, namun atas pertimbangan efisiensi daya saing nasional dan global. Sebelum sesuatu obyek (misalnya sentra atau calon sentra industri kecil) ditetapkan untuk dijadikan proyek pengembangan, perlu terlebih dahulu dinilai bahwa obyek tersebut layak dikembangkan untuk dijadikan proyek ataupun sasaran kegiatan. Kriteria kelayakannya utamanya didasarkan kepada pertimbangan-pertimbangan: (1) Kegiatan produksinya berakar dari terdapatnya 


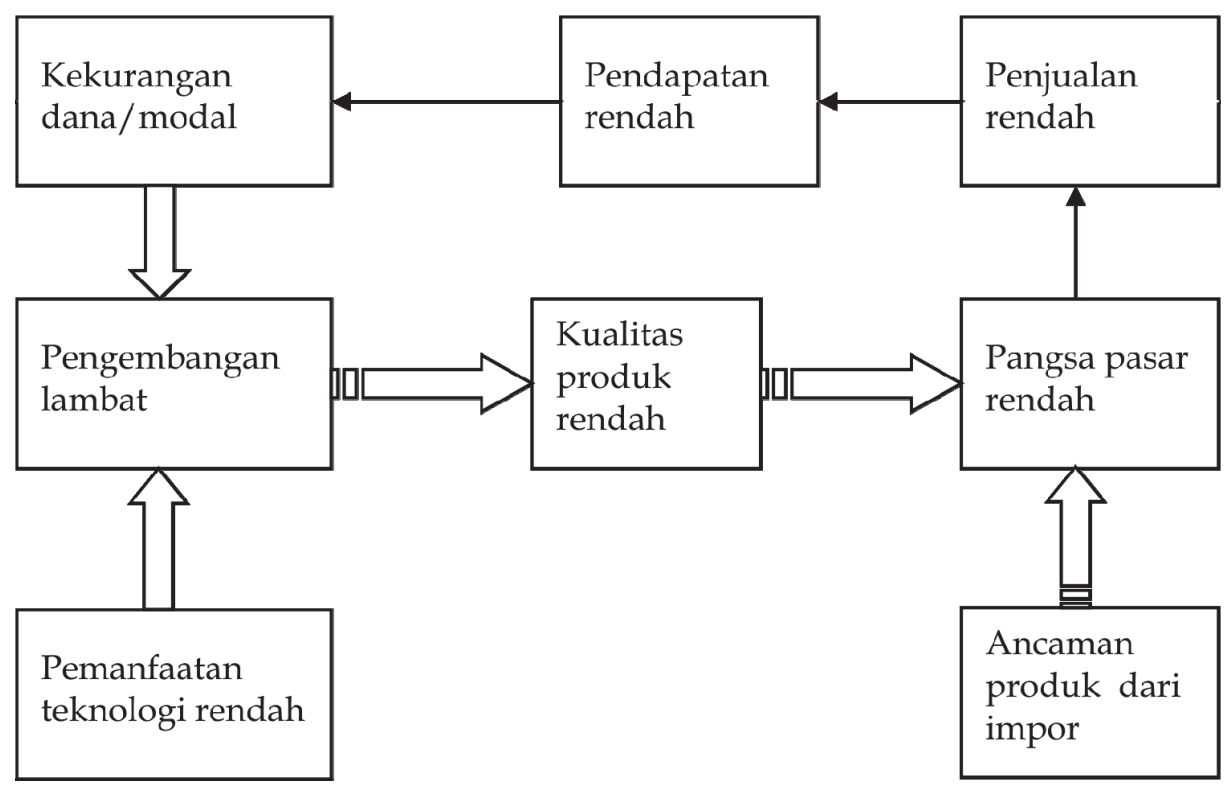

Gambar 6. Deskripsi Kondisi Umum UMKM Berdasarkan Survei

SDA dan talenta masyarakat setempat misalnya aset budaya kerajinan/seni tradisional; (2) Melibatkan tenaga kerja yang banyak khususnya pada penduduk setempat; (3) Menghasilkan nilai tambah agregat yang besar; (4) Dapat memicu pertumbuhan ekonomi di berbagai sektor terkait, khususnya di daerah yang bersangkutan; (5) Mempunyai prospek pasar yang potensial dan berkelanjutan, apalagi pasar ekspor; (6) Komponen-komponen kegiatan industri di dalamnya mempunyai prospek kelayakan finansial yang menjanjikan, sehingga hasil kegiatan pembinaan akan dapat mewujudkan kegiatan usaha industri kecil menengah yang secara komersial dapat berjalan dan tumbuh berkembang secara mandiri dan sehat (tanpa membebani pemerintah dengan subsidi maupun biaya pembinaan terus menerus).

Berdasarkan uraian secara garis besar kebijakan dan strategi pengembangan tersebut, baik dari aspek internal maupun eksternal, maka dapat diklasifikasikan ke dalam masing-masing aspek mikro yang dihadapi oleh UMKM. Aspek-aspek tersebut melipui aspek pemasaran, ketersediaan modal, inovasi, bahan baku, peralatan produksi, tenaga kerja, pengembangan usaha dan kesiapan menghadapi lingkungan eksternal.

Selanjutnya berdasarkan masalah yang ditemukan dari hasil survei dan telah disajikan

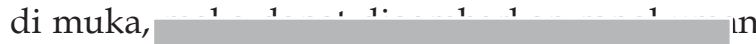
secara $g$ i $\quad$ ig dihadapi $\quad$ tg secara sir

Untı ig dihadapi in pemutus: di Provinsi ar bergerak apertaniar $\mathrm{u}$, maka ki is masalah . akukan ir in untuk, $P_{1} \quad$ lk sehingga $a$, untuk $\mathrm{m}$ akan me ra tujuan te katan da la peningka ar sehingga penaapatan akan meningkat. secara singkat mekanisme tersebut dipaparkan pada Gambar 7. 


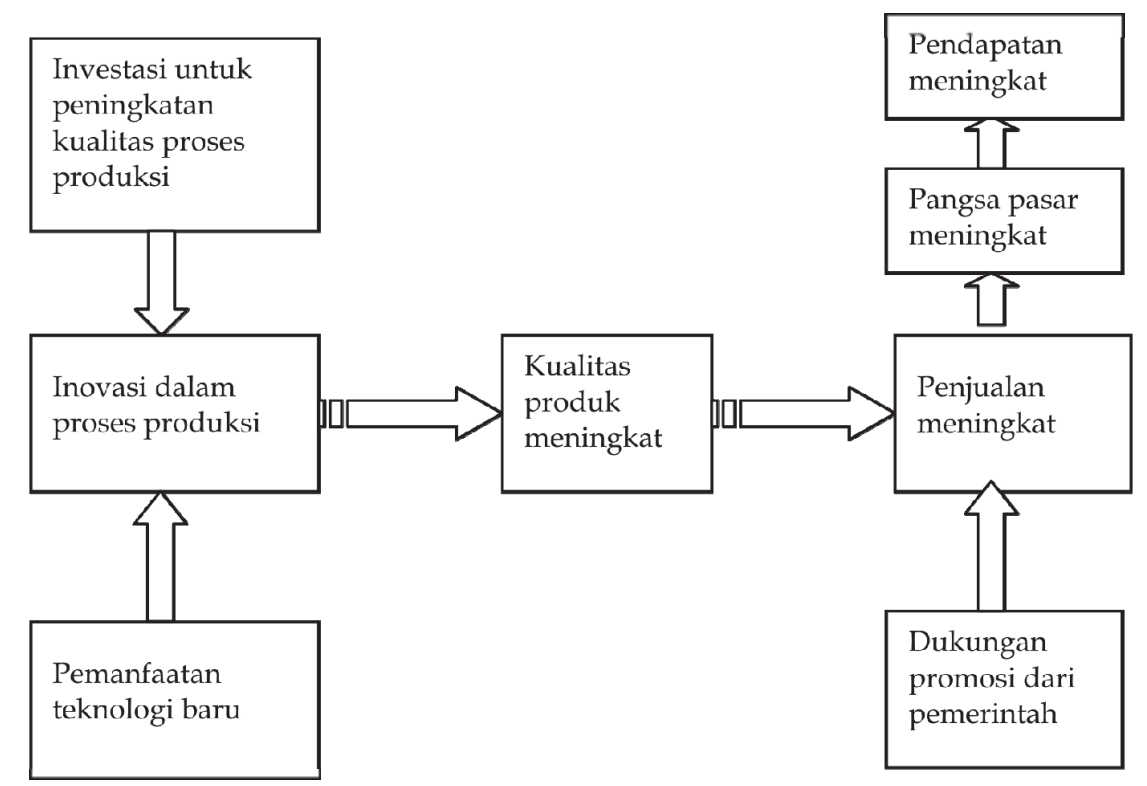

Gambar 7. Strategi Secara Umum Pengembangan UMKM

\section{SIMPULAN}

Dari hasil survei diperoleh beberapa masalah yang dihadapi oleh UMKM di Provinsi DIY, antara lain: (1) Pemasaran; (2) Modal dan pendanaan; (3) Inovasi dan pemanfaatan teknologi informasi; (4) Pemakaian bahan baku; (5) Peralatan produksi; (6) Penyerapan dan pemberdayaan tenaga kerja; (7) Rencana pengembangan usaha; dan (8) Kesiapan menghadapi tantangan lingkungan eksternal. Berkaitan dengan berbagai masalah yang dihadapai UMKM, maka diperlukan strategi untuk mengatasinya. Untuk mengembangankan UMKM tentu saja tidak hanya dibebankan pada UMKM sendiri namun harus memperoleh dukungan seluruh stake-holders. Dukungan termaksud diharapkan datang dari asosiasi pengusaha, perguruan tinggi, dan atau dinas/instansi terkait di lingkungan pemerintah kabupaten/kota dan Prosvinsi. Di samping itu diperlukan kebijakan pemerintah yang mendorong pengembangan UMKM. Pengembangan UMKM di DI Yogyakarta pada dasarnya adalah percepatan transformasi UMKM dari fase formasi menuju fase stabilisasi. Dalam rangka pengembangan UMKM tersebut, maka direkomendasikan berbagai ke- bijakan dan strategi meliputi: (1) Berbagai pelatihan dalam pengembangan produk yang lebih variatif dan beorientasi kualitas dengan berbasis sumber daya lokal; (2) Dukungan pemerintah pada pengembangan proses produksi dengan revitalisasi mesin dan peralatan yang lebih modern; (3) Pengembangan produk yang berdaya saing tinggi dengan muatan ciri khas local; (4) Kebijakan kredit oleh perbankan dengan bunga lebih murah dan proses lebih sederhana sehingga akan mendukung percepatan proses revitalisasi proses produksi; (5) Peningkatan kualitas infrastruktur fisik maupun nonfisik untuk menurunkan biaya distribusi sehingga produk UMKM akan memiliki daya saing lebih tinggi; (6) Dukungan kebijakan pengembangan promosi ke pasar ekspor maupun domestik dengan berbagai media yang lebih modern dan bervariatif.

\section{DAFTAR PUSTAKA}

Astungkoro, R.M. 2010. Kebijakan dan Strategi Pemberdayaan UMKM di Provinsi DIY. Materi Diskusi, Diskusi Tengah Tahun 2010 Kerjasama FE UAJY dan ISEI Ca- 
bang Yogyakarta. Yogyakarta 29 Juni 2010.

Hanke, J.E. and Reitsch, A.G. 1998. Business Forecasting. Sixth Edition. London: Prentice-Hall International Ltd.

Kountur, R. 2003. Metode Penelitian untuk Penelitian Skripsi dan Tesis, Cetakan 1. Jakarta: Penerbit PPM.

Krisnadewara, P.D., dan Sri Susilo, Y. 2006. Permasalahan Industri Kecil Pascagempa Bumi: Survei pada Beberapa Industri di Kabupaten Klaten, Jawa Tengah. Kinerja, Vol. 10, No. 2, hal. 162-171.

Kuncoro, M. 2009. Metode Riset untuk Bisnis E Ekonomi: Bagaimana Meneliti $\mathcal{E}$ Menulis Tesis?, Edisi 3, Cetakan 1. Jakarta: Erlangga.

Pickton, D.W., and Wright, S. 1998. What's SWOT in Strategic Analysis?, Strategic Change, 7 (1998), pp. 101-109.

Rangkuti, F., (2002), Analisis SWOT Teknik Membedah Kasus Bisnis, Cetakan III, PT. Jakarta: Gramedia Pustaka Utama.

Sekaran, U., and Bougie, R. 2010. Research Method for Business: A Skill Building Approach, $5^{\text {th }}$ Edition. USA: John Wiley and Sons Inc.

Singarimbun, M., dan Effendi, S., (Editor). 1989. Metode Penelitian Survei, Edisi Revisi, Cetakan 1. Jakarta: LP3ES.

Sri Susilo, Y., dan Sutarta, A.E. 2004. Masalah dan Dinamika Industri Kecil Pasca Krisis Ekonomi, Jurnal Ekonomi Pembangunan,
Vol. 9 No. 1, Juni 2004, hal. 65-78.

Sri Susilo, Y. 2005. Strategi Survival Usaha Mikro-Kecil (Studi Empiris Pedagang Warung Angkringan di Kota Yogyakarta), Telaah Bisnis, Vol. 6 No. 2, Desember 2005, 161-178.

Sri Susilo, Y., dan Krisnadewara, P.D. 2007. Strategi Bertahan Industri Kecil Pasca gempa Bumi di Yogyakarta, Ekonomi dan Bisnis, Vol. 9 No. 2, Juni 2007, hal. 127146.

Sri Susilo, Y. 2007. Masalah dan Dinamika Usaha Kecil: Studi Empiris Pedagang Klithikan di Alun-alun Selatan Yogyakarta, Jurnal Ekonomi, Vol. 12 No. 01 Maret 2007, hal. 64-77.

Sri Susilo, Y., Krisnadewara, P.D., dan Soeroso, A. 2008. Masalah dan Kinerja Industri kecil Pascagempa: Kasus di Kabupaten Klaten (Jateng) dan Kabupaten Bantul (DIY), Jurnal Akuntansi Bisnis dan Manajemen, Vol. 15 No. 2, Agustus 2008, hal. 271-280.

Tarigan, Y.P., dan Sri Susilo, Y. 2008. Masalah dan Kinerja Industri Kecil Pascagempa: Kasus pada Industri Kerajinan Perak Kotagede Yogyakarta, Jurnal Riset Ekonomi dan Manajemen, Vol. 8 No. 2, Mei 2008, hal. 188-199.

http://www.depkop.go.id

http://www.bps.go.id 